\title{
An appreciation of Dr Steven Pfeiffer, 1940-2007
}

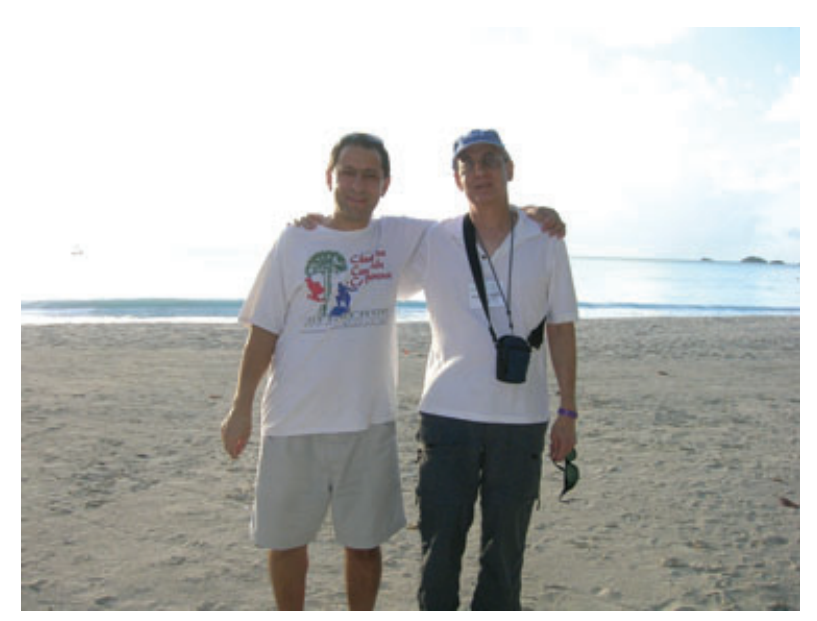

Steve Pfeiffer (right) and Tony Futerman at the meeting in Antigua in December 2006.

Soon after this special edition of the Journal of Neurochemistry went to press, we were informed of the sad news that Steve Pfeiffer had succumbed to cancer after a 2-year struggle. Steve was a loyal friend, a wonderful colleague, and his interactions with many scientists in the fields of glial cells and glycosphingolipids were always positive and stimulating. He will be greatly missed by his family and friends.

A detailed obituary of Steve can be found on the ASN website, and also in the Hartford Courant on Monday, August 27. What follows are thoughts from two friends, who got to know Steve well over the past few years. One of us (AF) was a co-chair of the symposium to which this special issue is dedicated, and spent the year or so before the symposium working on a day-to-day basis with Steve, so much so that over 1300 e-mails were exchanged! It seems more than a little strange not to be consulting with Steve now about the contents of this short note.

Steve had a productive research career, mainly in the field of myelin biology. He published his first paper, on selecting synchronous populations of mammalian cells, in Nature in 1967, and after that, moved to the study of Schwann cells, glial cells, and oligodendrocytes. This led him to the study of galactolipids and other glycolipids, and in the 1990s, he became an active member of the sphingolipid community and was a regular participant at many conferences in this field. He was particularly interested in the possible roles of lipid rafts in myelin function, and lectured on this issue at recent meetings.

Apart from his scientific contributions, Steve was simply a great person to know and spend time with. By way of example, at a recent Gordon Conference, Steve was asked to chair a 'poster session', in which mainly young scientists were asked to give short 5-min talks. Steve was asked to chair this session, as we felt his easy-going manner, and excellent interactions with students and postdocs, would be perfectly suited for this task. At the ISN Neurochemistry Conference in Antigua, Steve was his usual bubbly self and maintained his sense of humor, despite the fact that at the time he was undergoing a number of unpleasant treatments for cancer. Steve was in particularly good form when he met the Prime Minister of Antigua, and when he chaired the closing session of the meeting! That was the last time that we saw him, though emails continued to flow back and forth till as recently as August 3, when Steve wanted to discuss the role of myelin proteins in a mutant mouse.

Steve is sadly no longer with us. We will cherish the memories of all of our wonderful interactions with him.

Anthony H. Futerman

Weizmann Institute, Rehovot, Israel

Gerrit van Meer, Utrecht University, Utrecht, The Netherlands 